\title{
Technoscience, Hermeneutic and Society Oriented to the Person
}

\author{
JUAN R. COCA, ISABEL CABALLERO CABALLERO, \\ FRANCISCO J. FRANCISCO CARRERA, ANABEL PARAMÁ \\ GIR Trans-REAL lab, Faculty of Education of Soria, 42004 Soria, University of Valladolid, Spain \\ Email: juancoca@soc.uva.es
}

\begin{abstract}
This article becomes the first step towards technoscience as an opened and inter-penetrated enabler. For this the authors develop a theoretical and hermeneutical analysis of the techno-scientific system. A brief history of the modern occidental science is presented. Later, this article offers the first approach to a trans-subjective or trans-personal theory within the Latin American context. The authors show different reactions to the so-called 'monologated scientific system' in relationship to the hermeneutic of the person. Later the authors show a more dialogistic system in which other epistemic views are considered. These are connected with the philosophy of wisdom, the theory of personal care, etc. In this sense, and finally, it is considered that the techno-scientific system could be inter-penetrated for the psychic and social scope. In fact, this affirmation is defended to reach a scientific personal progress in a permanent dialogue with other wisdom knowledge.
\end{abstract}

Keywords: science, society, person, opened, interpenetration

\section{INTRODUCTION}

From the beginning of humanity, human beings have been doing technoscience in order to develop three perfectly caring and supportive subjects: a) as far as Theory is concerned, it is related to the knowledge of the laws which apply to observable happenings; b) when it comes to Practice, we should consider the practical application of the choice between good and evil; and, of course, last but not least, c) the idea of techné itself, such as, for example, the ability to make and manipulate things as a natural addition to any given thing. In any case, frequently this is limited to a fundamentally technical area, that is to say, to the construction of tools and appliances for improving their living conditions. As time went by, human beings looked towards understanding nature in order to continue advancing their scientific knowledge up until the present day.

In the beginning, technoscience was scientific and limited to just a few people, as such, it did not have many repercussions or effects on social relations. When it was offered to more people, it definitely had a major effect on society. As it reached this point, major controversies began to arise between scientists and society (Galileo's and Server's cases, for example). After all, scientists did not remain separated from the society. As science advanced, so technoscience grew. It was here, because of the political and economic interests, that other types of differences 
with society began to spring up besides the ethical problems. And so there were a wide index of social questions concerning society and science to be considered as highly relevant. The recent advancement of science has been spectacular and the scientific frontier became potentially endless. Similarly profound has been the impact of modern science on the society and on the man himself. And yet, the universal acceptance of science by society is still limited and in need of a more effective transmission of the intellectual and cultural value of science. A large fraction of society looks at science with fear and suspicion and views a science-dominated world as unbalanced and full of pain and peril rather than full with opportunity, hope and new freedoms. For this reason, to avoid these problems, in this article we opt for a renovation of the current techno-scientific system framed within a personalized conception.

So, in the following pages technoscience, society and person will be mixed, in what we will define as a transgressor or heterodox vision of the epistemologic and ethical protocols of modernity. This ends inevitably in a new interpretive-comprehensive paradigm of a radically hermeneutic nature. It is necessary to mention that from now on we will speak exclusively about science-technology as a historical accident, not a pre-determined one, but emphasizing our social 'here and now' historic accident, and not of technoscience, because in any historical perspective it is difficult to determine at what point technoscience begins to be a whole new construct and stops being a science. That would be the case, of course, especially if we conceive science to be an 'episteme' (Foucault 1984). In other words, it is to be understood as an exhausted configuration within the same particular and historical encirclement; or rather as a historically determined regime knowing and holding its own genuine rules from an illustrated-modern origin. To the best of our judgment, the distinction is clear, but this problem does not concern us in this text.

In an ontological, epistemological and ethical-political way of the hermeneutic vision, we have to focus the problem of the unfinished construction of the person from a triple objective perspective of the subjectivity in a historical and specific horizon, 'here and now. Following the general plan of the Foucaultian work, firstly, the 'myself' as a plectic-emergent being achieved a dynamic place of variable crossing of multiple and heterogeneous flows of communication action. Secondly, 'power' is considered as a relational-immanent dimension where the subjects acquire the ability to determine and orientate (in a reciprocal but unequal way) the frame of selective actions which define them, within the social area inscribed in its own organized domain. Thirdly, 'knowledge' has a specific relation with 'Truth' regulated by agreements with the practice-speeches, where they are enabled in one 'here and now', a few objects that do not pre-exist this rational act, which are not even a consequence of an ex-nihilo creation by language.

Competing with the technoscience configuration of the individual as person (Argamakova 2017) we are forced to provide a context for our reflections. On the one hand, in an 'exceeded modernity', in the 'post-electronic world' based on the planetary proliferation of the migratory and electronic flows, which endures a very deep alteration of the imaginary modern one in the relation with 'myself', with others and with the world. In a planetary 'hyper-space' of disputes and symbolic negotiations by means of which individuals and groups seek to annex the global thing to his own practices of the modern thing (Appadurai 2001). On the other hand, in a 'reflexive modernity' which is perceived itself as a topic and a problem (opened autocratically to a new global dialogue between cultures), but at the same time determined by the imperatives of risk as a self-organizing principle of a social system based on the connection (with ideological ends of social control and economic profitability) of this structure of means necessary for the resolution of the problems that have been generated by the own system recursively (Beck 1992). 
The paper describes and proves the following hypotheses: there is a close relationship between scientific development, society and person, so that one is influenced by the other and vice versa. The hermeneutical approach can help to understand numerous issues related to technoscience.

\section{THE SOCIAL EVOLUTION OF MODERN SCIENCE}

The 20th century placed the scientists in the social life; however, they were criticized for being isolated from this social life due to the idea that their work was forced upon society. In fact, at the beginning of the 20th century, many researchers were thinking that participating in the public debate was incompatible with their objectivity. At present this situation has changed as the social presence of movements has increased placing it along with the interdiction related to the authority of science (Bowler, Morus 2005).

This evolution of the science brought on the advancement of knowledge and had a major implication on science within society. Nevertheless, the social-economic changes transgressed one of the principles of science: humanism. Barnes observed the non-existence of a humanist link in the scientific occupation. What he saw instead were elements of competition, development, evolutionism, omnipotence, reputation, etc. (all the same faults that exist in our present society) (Barnes 1985). At the same time, it has also generated controversy, disputes, plagiarism, and so forth between scientists and has shown up ethical problems. All this has brought science above society, and at the same time, it has caused the apparition of movements that call science into question.

At this point, it seems necessary to take a close look to the whole issue of science and scientific development nowadays from a triple perspective which gives room to all inherited conception of Science itself. First, 'ontological realism' (there exists a given reality with independent properties from the individual cognoscente). Secondly, 'epistemological realism' (there exists a specific number of laws that regulate the predictable behaviour of the reality). Thirdly, 'epistemological determinism' (it is possible to objectively know the 'objective' laws that unilaterally determine reality) (Cardoso 1989). Beyond the objective context of justifying science, now the sociological context of discovery is imposed: the interpenetration, the construction of the sense of this 'dumb' reality as such, waiting to start speaking, is an object of a symbolic cultural apprehension and is trans-subjectively (dis)located. Let us not lose the sight of the particular and collective interests, certainly corporative, where the 'suspects' turn objective knowledge into vehicles of a few exclusive relations of power determinants, by means of the operating technologies of the control and random of speech. As a matter of fact, we may fall into the trap which awaits us within the tedious task of fixing the limits of what can or cannot be known since this brings over something of an academic imperative.

The illusion of objectivity, this mirage based on the deceitful belief where we can describe reality as such, independent from the cognitive social affective properties of the individual cognoscente, seems to stay in interdiction of the same dynamics of arbitrary technological games. If the sacrosanct victory of the Technology such as the 'Event' represents, at first, the metaphysical consummation of the oblivion of the being in his essential difference (the absolute control of what has to come here and now), it comes with a demanded break from experience contrary to knowledge. If this knowledge is ruled 'anteriori' of the predicted and advanced thing, that represents the recovery of a radical sense of existence as knowledge 'posteriori', only revealed in the same singular and unrepeatable experience of what always is known as the 'other one' (Agamben 2006). We should affirm, therefore, that important decisions do not happen as a result 
of an exercise of arbitrary preference, or by means of a foundation guaranteed in the universal truth. Somehow we are always half-way (Rorty 2009).

In the century we are living in, science and technology do not go by different means. Both have joined a techno-scientific common system. The consequences of similar alliances are incomprehensible, but we can suspect some are not to be positive at all. We can affirm that the present is dominated by what is called in a generic way (bio) technoscience (Coca, Valero 2010; Palazzani 2015), in reference to the importance of biotechnology in the current era. From the power that it addresses as authentic bio power, the regulator of the whole existence, at the beginning of the 21 th century the new system generated diverse ethical disputes for the use of the technoscience and took the decision itself on behalf of techno-scientific agents and the professionals of the sector. We are at the beginning of the century and already the first horizons of the relation are spied between technoscience and society, even though it remains great for glimpsing facing the rapid advance of the technoscience, especially in the biomedical field.

\section{PERSONALISED MAKE-UP CREATION/INVENTION OF THE SCIENTIFIC SYSTEM}

The scientific system had a deep internal transformation; it could be called new social cosmo-vision (Oliver 2003). This new cosmo-vision had its major push in the time before the Second World War, because the social 'western' system lost authority, as it was granted to the scientists (Luhmann 1996). In the same way, a material and non-interference support was granted to it in the scientific development of the time, thinking that this would end up with a better standard of living and a big range of choice for the majority of society. This meant that the scientific subsystem was originating a series of problems or possibilities with a high level of risk. One of the most typical examples of this fact comes from biotechnology, and before that, nuclear science which brought with it a high number of uncertainties and social and ecological risks such as the following: the new alliance between Science and Power, the double innovative and expansionist logic of Capital and its schools of environmental destruction and unusual increases in social differences in the distribution of the wealth generated. All this leads us towards the following question: Are these the big questionable consequences of the technoscientific 'achievements'?

The universal acceptance of science by society is still limited. A good fraction of society fears the impact of science on the man and the environment and many in society believe that science sets its own conditions and imposes its own values on society. Clearly, modern society fails to fully appreciate what science is providing for it, in spite of the benefits it derives from science and in spite of the fact that modern society will cease functioning without science and science-based technology (technoscience). All too often society takes the benefits of scientific discovery for granted and all too often it exaggerates out of fear or ignorance the potential impact and the risks of new scientific knowledge. Society, therefore, needs to accommodate science's unique ways of functioning and adjust to new scientific discovery, fully cognisant of the fact that scientific knowledge comes with benefits, but also with peril and pain.

Repeatedly in the recent past the relationship between the scientists and society has been strained by several important issues - embryonic stem cell research and climate change to name just two. In such instances, society is not just sensitive to what science does or does not do, but oftentimes society overreacts casting aside long-range benefits. The recent reactions regarding scientific data used to evaluate climate change make the point. An important aspect of the scientific literacy of society then should be enhancement in society's ability to recognize that while even in science errors are made, inherent in the method of science is the capability to discover and to correct such errors (Shamoo, Resnik 2003). 
Nonetheless, it is obvious that Science is an important part of human activity. People should understand the important value of Science, both for its cultural implications as well as for its economical impact. For this reason there were many thinkers who saw the need to reform the subsystem of science. This reconfiguration keeps a transforming perspective but is not a devastating and self-destructive approach. In other words, the expositions that are going to appear hereinafter do not oppose scientific development as the previous ones did. In this context it is possible to verify that numerous offers have been carried out in a summarized and widespread way centred on the fundamental aim of this text, and can be included in three big groups. In each group it is verified that the mentioned authors have focussed on someone with the fundamental characteristics of the technoscientific system.

Due to the dual nature of science, technoscientific activity gave room to innovations and progress but also to risks, of such a magnitude that thinkers, like Gabriel Marcel (2001) or Jacques Ellul (1960), expressed deep reservations to the above-mentioned activity because of its potential eschatological nature. We can read numerous works which are not fully confident of scientific activity. In the Lusitanian area, Leonardo Boff, in reference to this aspect, affirmed that reverence had been abandoned, this was essential in taking care of life and its fragility (Boff 2002).

This related to the need to mix science with a more reverential perspective of nature. Later he stated that it was necessary to change things, but with self-reflection, and so to propitiate a new instrumental, emotional and spiritual reason that converted science, technology and critique into medicines for human beings and our environment. Therefore, and due to the fact of not having a self-reflection period, the instrumental, emotional and spiritual reasons become the crux of the matter in the current situation. Other critical position with the current development of subsystems of science has been made by Bielecki, Nieszporska (2017) and Murillo (2005).

This thinker uses Gadamer's position on 'Truth and Method' as a springboard to say that at the base of science, our environment is being turned into an enormous workshop up to the point where scientific advances show the will to dominate the natural way and even human beings themselves. Against this, Murillo suggests incorporating scientific and technical knowledge into a 'Philosophy of Wisdom'. This philosophy would put the scientific subsystem into human hands; nowadays this approach has been undertaken by authors, such as Mauricio Beuchot, Andrés Ortiz-Osés, Francesc Torralba as well as different old personalistic thinkers. This position departs from the fact that progress of factual sciences has to be always positive, in such a way that it is indispensable to interpenetrate (in a Luhmannian sense) this subsystem with others.

It is worth noticing to mention here that Josep Maria Esquirol came up with a third option. Recognizing the mentioned ambivalence of science itself, he thought that it was necessary to complete the scientific cosmo-vision with 'the cosmo-vision of respect. This cosmo-vision, which does not deny the most purely scientific approach, would make us more balanced and multi-dimensional subjects. This would be essential since nowadays both the superficiality and the imbalance are unequivocal symptoms of our society. With this, the cosmo-vision of respect comes closer to the paradigm of care, or a wise thought enters thus about the need of positioning itself deeper than science can reach, as it only contributes to a superfice. This respect also lines up with the idea of Kinsella and Pitman (2012) for whom phronesis should be reconsidered in most of the human professions in order to rescue practical wisdom in our lives.

These diverse possibilities, which we have briefly exposed, do not try to transform scientific rationality, but rather incorporate elements of control or interpenetration into the scientific 
system. Thus, it tries to prevent big catastrophes and to give meaning to science's activities, thanks to ethics, ontology and theology; and even to re-form this subsystem through anthropology as a fully human self-accomplishment.

Besides the axiological position exposed before, a lot has been written about trying to modify the rationality that directs the aforementioned subsystem. Paul Feyerabend (1992) suggested eliminating the methodological dogmatism of science, pleading instead for methodological anarchism. Another interesting position comes from the sociologist Boaventura de Sousas Santos.

This thinker shows that from the 16th century onwards the rational positioning has grown. This, of course, has given a lot of prevalence to science, placing it to the forefront of the most essential and pressing issues for western societies. In fact, the model of scientific rationality arising in this era, besides being global, was also totalitarian, in the way in which it denied a rational character to all those forms of knowledge that should not rule its epistemological principles and methodological rules (Santos 2001). In other words, they gave such a level of authority to scientific affirmations, which ended up by being a maximum expression of any possible reality.

The scientific conclusions were the only truth. For all that, it is perfectly feasible to say that the science subsystem has been living inside a paradigm, meaning that the above-mentioned activity has been truly ontological.

The model of rationality that has led us to modernity and has been developing since the 16th century clearly ends up configuring the social sciences in the 19th century. It is from that moment onwards that we can speak about a global 'western' model. In spite of being relatively diverse in its interior, it fought 'tooth and nails' against two forms of non-scientific knowledge: the common sense and the so-called humanities (Santos 2003). Before this, Santos spoke about a new paradigm: the emergent paradigm. This paradigm means that at present there is a scientific revolution taking place which was carried out by society itself. Therefore, this new paradigm is not a scientific but a social paradigm (Santos 2001).

As far as the Portuguese thinker's ideas are concerned, other views are definitely germane, for example, those offered by Funtowicz, Ravetz (1990) and Funtowicz, Liberatore (2003) since they have developed the concept of post-normal science. This concept would imply those problems related to the survival of ecosystems and the well-being of people. This new subgroup of science would have the characteristic of including all the problems that show a high level of risk and uncertainty. Also in this group we can include the hermeneutization of science, looking to transform scientific inscrutability, which can end up by being a more analogical and hermeneutic rationality, where science's rationality turns into personal rationality.

Besides the transformation we have mentioned (Sousas's emergency, the post-normal science of Funtowicz, Ravetz or the hermeneutication of the science), we have to take into account as well the modification in the perception of the nature, which stopped being considered God's creation (as it was in the Middle Ages), to be considered, some would say, a set of raw materials to be exploited (we can think here in the industrial revolution), to get lately to a new view where it would be understood as a 'oikos' (in our home). Therefore, after all these changes about the true nature of Science and its scope of action, it seems clear to us that a dialogue or negotiation is getting more and more necessary between experts and the affected parts of the society, both in the environmental and political realms.

The aspects mentioned above brought to the forefront the concept of society at risk. This is due to the fact that the activities carried out in the social subsystems dependent on science 
are assumed to be potentially dangerous. At this respect, Ravetz (1997) adds some aspects to post-normal science by saying that precaution is fundamental as a founding premise. This author affirms that science would have to follow the principle of 'it would happen if' (that is to say: 'what if').

Thus sufficient knowledge would be obtained that would allow us to intervene in our environment to minimize the potential risks or to look for alternatives. Ravetz (1997) postulates that the system of science has moved from its core to its margins where the level of uncertainty is very much greater. Against this, factual science will be obliged to enter in a dialogue with other aspects of knowledge which may have been ignored so far. Therefore, we can say that the thoughts of Chin (2014), Funtowicz, Ravetz (1990), Beck (1992), Fujigaki (2018) and Luhmann (1996), among others, show us that the rationality of science is turning into a scientific rationality of risk.

It seems that the risk rationality will be lamed if we are not aware that in this possible risk the ontology of person could be in danger. All of this required more research and also more financing of the technoscience policy. But this is a subject for other research.

\section{FINAL REFLECTION}

We have seen that the scientific subsystem possesses a dual character nowadays. This has caused an internal transformation in the above-mentioned subsystem, passing from a dominant paradigm to an emergent one. All of this means that we could have two positions in the near future: an expectant position and an activist one.

The first one implies a motionless perspective and therefore would have us merely waiting in order to see what will happen and, depending on that, then deciding whether to act or not. In this case, the sense of science goes towards a greater independence of society and maintenance of our own totalitarian model of modernity.

The second position proposes something quite different, that is to say, that it would lead us to take part and by doing so fully realize the commitment of the action. In this case, the sense that the subsystem of science takes will be the responsibility of those who take part in it. This one is exactly the position that exists currently in science, known as 'Science, Technology and Society', of which we form a part. This seeks to have a voice in the academic arena, on the Internet, in the public opinion and so on.

A personalized configuration of the technoscientific system brings with it the sense of science consisting of a relational configuration of science (Colucci-Gray 2013; Coca et al. 2016). In such a way in the scientific subsystem a permanent interpenetration would take place with the psychic system. Therefore the environment of the psychic system, which in this case would be the scientific subsystem, would be much closer to the person.

The above-mentioned interpenetration or relationality is important in two aspects. First, as an axis of the action of the system, that is to say, the extension of the area of action of science to the whole humanity equally and without exclusion. Secondly, as an epistemological area which will be founded on the principle of the Husserlianistic view of a change in European sciences (1970).

A change is based on the need through which humanity exists as a transcendental community needing a transcendental intersubjectivity. Nevertheless, this Husserlianistic community remains as something incomplete. That is why we need to resort to the 'gnoseologic theory' proposed by Martin Buber, where the objective knowledge is replaced and becomes present, and therefore, it is a more relational knowledge altogether. In other words, when we know 
the natural things, they 'say' something to us, and we can establish a personal relation with them. 'In such a way that the person who turns towards the world and, contemplating it enters into a relationship with it, it will have inside itself' (Buber 1965).

Summarizing, our scientific position is intercultural, because we move from the monological idea of identity to the centre on the dialogical and mediating idea of the 'ipseity', as the 'myself' is permanently recreated across the diverse incorporations of the 'alterity' 'in our multiple personalities' 'to manage to be' (that is, to become) a possibility. We are alluding here to the possibility of managing to be in our constant miscegenations and trans-subjective intersections, which never turn the individual into what it is, but into what it can manage to be.

We think that it is necessary to transform the diverse characteristics that the techno-scientific subsystem presents into a more personal direction which must be interpenetrated with the psychic or relational system. Thus, the sense of science will stop being a hermetic and enclosure field in order to become a more open realm which will remain full of possibilities and give a lot of room to both the scientific community and the 'everyday man in the streets' to 'experiment the world again' and improve upon all the greatness achieved in the past.

\section{CONCLUSIONS}

An important part of society fears the impact of science on the man and the environment, and the belief that science sets its own conditions and imposes its own values on society may be spread. Clearly, the modern society fails to fully appreciate what science is providing for, in spite of the benefits it offers and in spite of the fact that our modern society will cease functioning without technoscience. All too often society benefits from scientific discoveries and all too often it exaggerates out of fear or ignorance the potential impact and the risks of new scientific knowledge.

Society, therefore, needs to accommodate science's unique ways of functioning and adjust to new scientific discoveries, fully cognisant of the fact that scientific advances come with benefits, but also with risks. For which, it is necessary that all scientific advances reach the citizen and they allow the development of this one as person.

A hermeneutical perspective on science is essential now that the structure that organizes and explains the world has lost its persuasive force. The desire to see science as a reference to a deeper truth or field of essences in nature - as well as the movement that holds that there is nothing beyond ourselves and that any description we give of nature is simply a random projection of our interests - is a consequence of the positivism from which the hermeneutic perspective can help us get rid of. With a hermeneutical perspective, one is not faced with having to choose between postulating a final, hidden truth, on the one hand, or calling truth a matter of arbitrary convention, on the other.

Received 13 March 2018 Accepted 4 July 2018

\section{References}

1. Agamben, G. 2006. Infancy and History. On the Destruction of Experience. London: Verso.

2. Appadurai, A. 2001. La modernidad desbordada. Dimensiones culturales de la globalización. MontevideoBuenos Aires: Trilce-Fondo de la Cultura Económica.

3. Argamakova, A. A. 2017. "Between Technological Utopia and Dystopia: Games and Social Planning", Epistemology \& Philosophy of Sciencie - Epistemologiya I Filosofiya Nauki 54(4): 150-159. DOI: 10.5840/ eps201754479.

4. Barnes, B. 1985. About Science. Oxford: Blackwell.

5. Beck, U. 1992. Risk Society: Towards a New Modernity. London: Sage. 
6. Beuchot, M. 2004. Antropología filosófica. Salamanca: F. Emmanuel Mounier.

7. Bielecki, A.; Nieszporska, S. 2017. "The Proposal of Philosophical Basis of the Health Care System", Medicine, Health Care and Philosophy 20(1): 23-35.

8. Boff, L. 2002. El cuidado esencial. Ética de lo humano, compasión por la Tierra. Madrid: Trotta.

9. Bowler, P. J.; Morus, I. R. 2005. Making Modern Science: A Historical Survey. Chicago: The University of Chicago.

10. Buber, M. 1965. The Knowledge of Man: A Philosophy of the Inter-human. Transl. by M. S. Friedman and R. G. Smith. New York: Simon and Schuster.

11. Cardoso, C. F. S. 1989. Introducción al trabajo de la investigación histórica. Barcelona: Crítica.

12. Coca, J. R.; Francisco Carrera, F. J.; Fernández Tijero, M. C. 2016. "Le frontiere della conoscenza scientifica in un futuro marcato dalla persona: Una visione dalla socio-ermeneutica pluri-analogica", Per la filosofía 33(96): 85-94.

13. Coca, J. R.; Valero-Matas, J. A. 2010. “(Bio)technological Imageries about Human Self-construction on Spain Context: A Preliminary Study", Studies in Sociology of Science 1(1): 58-66.

14. Colucci-Gray, L.; Perazzone, A.; Dodman, M.; Camino, E. 2013. "Science Education for Sustainability, Epistemological Reflections and Educational Practices: From Natural Sciences to Trans-disciplinarity", Cultural Studies of Science Education 8(1): 127-183.

15. Chin, C. F. 2014. "Subliming and Subverting: An Impasse on the Contingency of Scientific Rationality", Journal of the Philosophy of History 8(2): 311-331.

16. Ellul, J. 1960. El siglo XX y la técnica. Análisis de las conquistas y peligros de la técnica de nuestro tiempo. Barcelona: Labor.

17. Feyerabend, P. 1992. Tratado contra el método. Esquema de una teoría anarquista del conocimiento. Madrid: Tecnos.

18. Foucault, M. 1984. La arqueología del saber. México: Siglo XXI.

19. Fujigaki, Y. 2018. "Interactions Between Scientific and Social Rationality: Recommendation of Intermediate Layer for Transdisciplinary Sustainable Science", Sustainability Science 13(2): 369-375.

20. Funtowicz, S.; Liberatore, A. 2003. "'Democratising' Expertise, 'Expertising' Democracy: What Does this Mean, and Why Bother?", Science and Public Policy 30(3): 146-150.

21. Funtowicz, S. O.; Ravetz, J. R. 1990. "Post-normal Science: A New Science for New Times", Scientific European 169: 20-22.

22. Gadamer, H. G. 1977. Verdad y método. Salamanca: Sígueme.

23. Husserl, E. 1970. The Crisis of European Sciences and Transcendental Phenomenology. Transl. by D. Carr. Evanston: Northwestern University Press.

24. Kinsella, E. A.; Pitman, A. (eds.). 2012. Phronesis as Professional Knowledge Practical Wisdom in the Professions. Rotterdam: Sense Publishers.

25. Luhmann, N. 1996. La ciencia de la sociedad. México: Universidad Iberoamericana-Anthropos - ITESO.

26. Marcel, G. 2001. Los hombres contra lo humano. Madrid: Caparrós.

27. Murillo, I. 2005. "Ciencia y ética personalista”, Analogía Filosófica 19(1): 45-68.

28. Oliver, E. V. 2003. "The Machine of the World and the Man-machine: Cosmo-vision and Individual Consciousness in Times of Certainty and Times of Doubt", Portuguese Studies 19: 122-144.

29. Ortiz-Osés, A. 2000. La razón afectiva. Arte, Religión y cultura. Salamanca: San Esteban.

30. Palazzani, L. 2015. "Ethics and Law in the Era of Techno-Science", Rivista di Filosofía del Diritto 4: 125-140. DOI: $10.4477 / 81828$.

31. Ravetz, J. 1997. “The Science of 'What-if”, Futures 29: 533-539.

32. Rorty, R. 2009. Una ética para laicos. Barcelona: Katz.

33. Santos, B. de Sousa 2001. Um discurso sobre as ciências. Porto: Afrontamento.

34. Santos, B. De Sousa 2003. Crítica de la razón indolente. Contra el desprecio de la experiencia. Bilbao: Desclée de Brouwer.

35. Shamoo, A. E.; Resnik, D. B. 2003. Responsible Conduct of Research. New York: Oxford University Press.

36. Torralba, F. 2005. ¿Qué es la dignidad humana? Barcelona: Herder. 
JUAN R. COCA, ISABEL CABALLERO CABALLERO, FRANCISCO J. FRANCISCO CARRERA, ANABEL PARAMÁ

\section{Technomokslas, hermeneutika ir visuomenė, orientuota $\mathbf{i}$ asmeni}

Santrauka

Šis straipsnis - tai pirmasis žingsnis plètojant atvirą technomokslą, kuriam ịtakos turi kiti mokslai. Autoriai teoriškai ir hermeneutiškai analizuoja technomokslinę sistemą, trumpai pristato šiuolaikinio Vakarų mokslo istoriją, transsubjektyvų ir transpersonalų teorinius požiūrius Lotynų Amerikos kontekste, parodo skirtingas reakcijas į vadinamąją „monologizuotą mokslinę sistemą", tai sieja su asmens hermeneutika. Straipsnyje aptariama dialoginè sistema, kiti episteminiai požiūriai. Tai saistoma su išminties filosofija, asmeninio rūpesčio teorija ir pan. Galiausiai svarstoma, kad technomokslinè sistema gali būti persmelkta psichologijos ir sociologijos. Ši nuostata ginama siekiant esminès mokslinès pažangos ir nuolatinio dialogo su kitais mokslais.

Raktažodžiai: mokslas, visuomenė, asmuo, atvirybè, persmelkimas 